\title{
Triatoma maculata, the vector of Trypanosoma cruzi, in Venezuela. Phenotypic and genotypic variability as potential indicator of vector displacement into the domestic habitat
}

\section{Roberto García-Alzate ${ }^{1,2}$, Daisy Lozano-Arias ${ }^{1,2}$, Rafael Matías Reyes-Lugo ${ }^{3}$, Antonio Morocoima ${ }^{4}$, Leidi Herrera ${ }^{2}$ and Alexis Mendoza-León ${ }^{1 *}$}

${ }^{1}$ Facultad de Ciencias, Instituto de Biología Experimental (IBE), Universidad Central de Venezuela, Caracas, Venezuela

${ }^{2}$ Facultad de Ciencias, Instituto de Zoología \& Ecología Tropical (IZET). Universidad Central de Venezuela, Caracas, Venezuela

${ }^{3}$ Facultad de Medicina, Instituto de Medicina Tropical (IMT), Universidad Central de Venezuela, Caracas, Venezuela

${ }^{4}$ Instituto de Medicina Tropical (IMT), Universidad de Oriente, Cumana, Venezuela

\section{Edited by:}

Rubén Bueno-Marí, University of Valencia, Spain

\section{Reviewed by:}

Jia Liu, Pfizer Inc., USA

Xanthe Vafopoulou, York University,

Canada

\section{*Correspondence:}

Alexis Mendoza-León, Laboratorio de Bioquímica and Biología Molecular de Parásitos, Facultad de Ciencias, Instituto de Biología Experimental (IBE), Universidad Central de Venezuela, Calle Suapure, Colinas de Bello Monte, Caracas 1041, Venezuela e-mail: amendoza50@gmail.com
Triatoma maculata is a wild vector of Trypanosoma cruzi, the causative agent of Chagas disease; its incursion in the domestic habitat is scant. In order to establish the possible domestic habitat of T. maculata, we evaluated wing variability and polymorphism of genotypic markers in subpopulations of T. maculata that live in different habitats in Venezuela. As markers, we used the $m t C y t$ b gene, previously apply to evaluate population genetic structure in triatomine species, and the $\beta$-tubulin gene region, a marker employed to study genetic variability in Leishmania subgenera. Adults of T. maculata were captured in the period 2012-2013 at domestic, peridomestic (PD), and wild areas of towns in the Venezuelan states of Anzoátegui, Bolívar, Portuguesa, Monagas, Nueva Esparta, and Sucre. The phenotypic analysis was conducted through the determination of the isometric size and conformation of the left wing of each insect (492 individuals), using the MorphoJ program. Results reveal that insects of the domestic habitat showed significant reductions in wing size and variations in anatomical characteristics associated with flying, in relation to the PD and wild habitats. The largest variability was found in Anzoátegui and Monagas. The genotypic variability was assessed by in silico sequence comparison of the molecular markers and PCR-RFLP assays, demonstrating a marked polymorphism for the markers in insects of the domestic habitat in comparison with the other habitats. The highest polymorphism was found for the $\beta$-tubulin marker with enzymes BamHI and Kpnl. Additionally, the infection rate by T. cruzi was higher in Monagas and Sucre (26.8 and 37.0\%, respectively), while in domestic habitats the infestation rate was highest in Anzoátegui (22.3\%). Results suggest domestic habitat colonization by T. maculata that in epidemiological terms, coupled with the presence in this habitat of nymphs of the vector, represents a high risk of transmission of Chagas disease.

Keywords: Triatoma maculata, Trypanosoma cruzi, vector, Chagas disease, epidemiology, architecture of wings, molecular markers, RFLP-PCR

\section{INTRODUCTION}

Triatomines (Hemiptera, Reduviidae, Triatominae) are bloodsucking insects that act as vectors of tripanosomatids such as Trypanosoma rangeli and T. cruzi (Kinetoplastida, Trypanosomatidae), the latter being the causal agent of American trypanosomiasis or Chagas disease. This is one of the parasitic diseases of great medical importance in the Neotropics. Chagas disease remains a public health problem in America, being distributed from the centralsouthern region of the United States to Southern Argentina and Chile; patients with this disease have been found in Canada and some European countries $(1,2)$.

Transmission of Chagas disease in Venezuela and elsewhere in South America has been traditionally associated with the domestic
(D) and peridomestic (PD) environments in rural areas with poor socioeconomic conditions and high presence of vectors. However, colonization by triatomines such as Triatoma maculata and Panstrongylus geniculatus of D environments has increased, whereas before these triatomines had been mostly associated with PD or wild (S) habitats (3). In Venezuela, T. maculata is found in most of the states comprising the country, with the exception of Táchira and Delta Amacuro. Distribution is established from 0 to $1,500 \mathrm{~m}$ of altitude, with natural habitats such as palms, dry trees, fences and bird nests, and rates of infection with $T$. cruzi lower than those recorded for Rhodnius prolixus. Apparently, as a result of anthropogenic changes, the characteristic habitats of $T$. maculata have changed the insect becoming domestic (4). 
The domiciliation of triatomines seems to be an event that can sometimes lead to the simplification of genotypic and phenotypic characteristics, which can be adaptive to macro- and microclimatic variations and reduction of wildlife mammals that serve as blood source, among others factors. These factors favor the dispersion and increase triatomine populations in anthropogenic niches (5, $6)$. There is suggestive evidence of a recent increase in adaptive capacity of $T$. maculata in populated areas, hence the importance of studying this vector (7).

The taxonomic position of triatomines has been revised through phenotypic studies using various methodologies, such as analysis of biochemical markers, e.g., isoenzymes, or morphometric techniques, e.g., variability analysis of the size and shape of anatomical structures (8-12), and genotypic assessment methods of polymorphism of genetic markers, e.g., the mitochondrial cytochrome $b(\mathrm{mtCy} \mathrm{b})$ sequence (13-15) and the ribosomal spacer region (ITS-2), among others. All of these methodologies have shown interspecific variability in different triatomines species and have been used to evaluate population genetic structure. The geometric morphometry analysis, which allowed differentiating domestic and wild insects of medical importance such as mosquitoes, and ontogenetic studies of triatomine populations have been useful in discriminating vectors, which cannot be identified by morphological or molecular variability studies (16-18).

The combined use of phenotypic methods such as geometric morphometry analysis and assessment methods such as genetic polymorphism of molecular markers would be useful in the evaluation of vector populations related to Chagas disease and the establishment of appropriate interventions for disease control. Analysis of changes in the wings, supported by the study of molecular markers such as $\mathrm{mtCyt} \mathrm{b}$, has been used in Colombia in the differentiation of species of Rhodnius (14). In Venezuela, comparative studies, both phenotypic and genotypic, on vectors of Chagas disease are scarce; one of these studies suggests a polymorphism related to the geographical origin of the specimens in the restriction patterns of the mtCyt b gene in T. maculata (4).

This work assesses the dispersion of this vector throughout $\mathrm{S}, \mathrm{PD}$, and $\mathrm{D}$ ecotopes in several Venezuelan states using both the phenotypic and genotypic approaches, in specimens of $T$. maculata captured in different regions of Venezuela. The phenotypic approach includes a geometric morphometry study to establish wing variability; the genotypic variability was evaluated through the polymorphism of the molecular markers $m t C y t \mathrm{~b}$ and the $\beta$-tubulin genes region. Previously, the $\beta$-tubulin marker has been used to establish genetic variability between Leishmania subgenera.

\section{MATERIALS AND METHODS STUDY AREA AND INSECTS}

Field work was conducted in the endemic Venezuelan states Anzoátegui, Sucre, and Monagas (east of the country); Nueva Esparta (northeast, Margarita island), Bolívar (south), and Portuguesa (west). Sampling was carried out following the method proposed by Schofield (19). Specimens of T. maculata were collected through a direct search by personnel previously trained; sampling was conducted twice/year in each region and the capture effort occurred at $5 \mathrm{~h} / \mathrm{man}$ by day or night for 5 -day visit to each region. A total of 26 locations distributed in these states were visited to collect, in periods of high and low precipitation, specimens of T. maculata, directly from ecotopes defined following previous criteria. In D habitat, attention was put on internal walls of the houses, rooms, roofs, furniture, and in the ceiling; external domiciles or PD habitat $(30 \mathrm{~m}$ around the exterior walls of the house), the area explored included farmyards, henhouses, and wood piles; and in S habitat (removed $30 \mathrm{~m}$ from the PD habitat), the area explored covered palm trees, tree holes, cave, and crops $(20,21)$. A total of 492 adult insects, male (M) and female (F), were collected and used in this study. Three indices were calculated; the colonization index was determined as CI $(\%)=100 \times$ total numbers of houses presenting nymphs/total number of houses with adults; the dispersion as DI $(\%)=100 \times$ number of locations with adults/number of locations studied, and infection index as II $(\%)=100 \times$ number of adults infected with T. cruzi/total number of adults captured. Specimens were dissected and their intestinal contents and/or hemolymph examined under the microscope for the presence of Trypanosoma; samples of the intestinal contents were used to evaluate the presence of $T$. cruzi and $T$. rangeli by means of a PCR assay (22). After dissection, the collected specimens were preserved in $70 \%$ alcohol and stored at $-20^{\circ} \mathrm{C}$ for further analysis. Colonies from each location were established in the laboratory for morphometry analysis.

\section{GEOMETRIC MORPHOMETRY ANALYSIS: METRIC DATA, SHAPE, AND SIZE VARIATION}

For each individual, only the left wing was examined and included in the analysis. The wings were mounted between microscopy slides and cover-slips and photographed using a digital camera Leica S6D. Nine landmarks (Figure 1A) were identified in each wing according to previous references $(18,23)$; the geometric coordinates of each landmark were digitized and shape variables (partial warps) were obtained using tpsDig Version 2 (24). Data were submitted to a discriminant analysis to examine differences in wing shape between male (M) and female (F) and statistical significant was evaluate by the Wilk's lambda statistics. For comparison of wing size between genders and among ecotopes within each gender, we used the isometric estimator centroid size (CS) derived from coordinate data $(10,15,23)$. Statistical analysis was carried out using the MorphoJ software package for geometric morphometric (25). Landmark coordinate $(x, y)$ configurations were registered and aligned using the Procrustes analysis and covariance analysis was implemented with proportions of re-classified groups and MANOVA. Then, wing shape variable and the CS were analyzed using the principal component analysis. For this analysis, $\mathrm{M}$ and $\mathrm{F}$ were processed separately due to the sexual size dimorphism of Triatominae. The relationship between shape and size was explored by a regression analysis. The significance of wing conformation due to landmark variation was established using the canonical variate analysis.

\section{DNA EXTRACTION AND MOLECULAR MARKER AMPLIFICATION}

Total genomic DNA was extracted from all six legs of each specimen using the Wizard Genomic kit (Promega, Madison, WI, USA. Cat. No. A1620). Purity and integrity of the DNA were determined by agarose gel electrophoresis. The same procedure was used to 


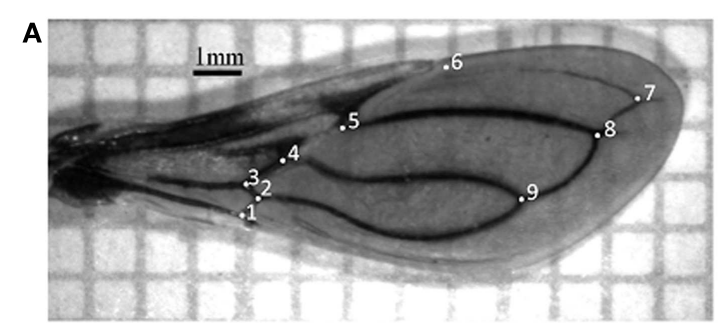

B

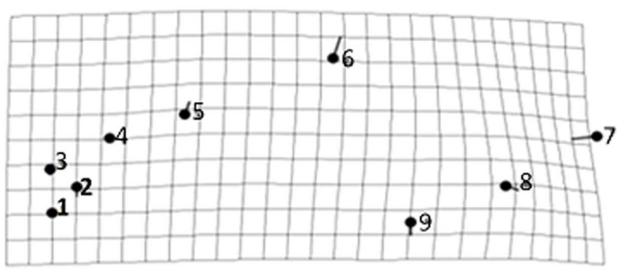

M

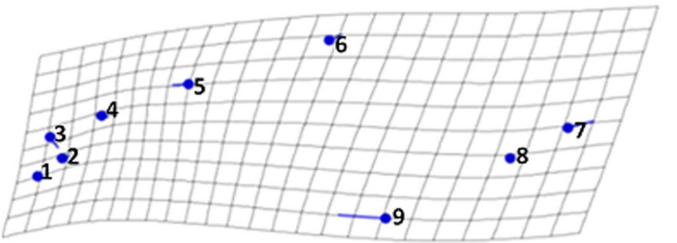

$\mathbf{F}$

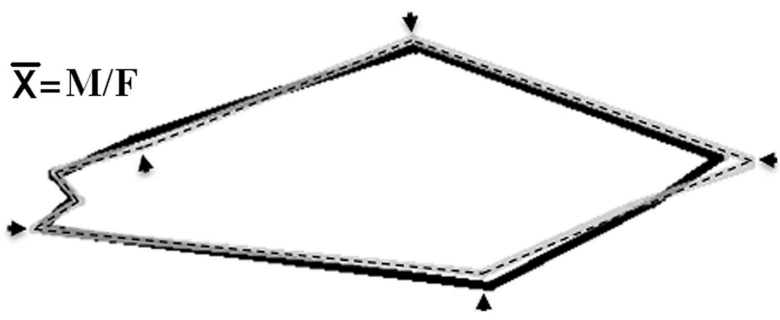

FIGURE 1 | Differences in wing shape between genders of Triatoma maculata from Venezuela. (A) Landmark points type I identified in wing of T. maculata. Numbering of points (PAR 1-9) refer to the arrangement followed to obtain the coordinates using tps Dig 2.0. (B) Differences in wing shape architecture of T. maculata. Differences in wing shape between male (M) and female (F) of T. maculata are represented by grids deformation and variation between homologous landmark (solid circles). After superposition to the homologous consensus $(\bar{X})$ between $M$ (solid lane) and $F$ (dashed lane), the differences in wing shape are represented by incongruence between homologous landmarks (arrows). different triatomine species $(28,29)$, and second, the $\beta$-tubulin gene region, a marker employ to study genetic variability in Leishmania subgenera $(30,31)$.

The $\beta$-tubulin primers were designed by multiplex alignment of similar genes available in the NCBI Genbank from Triatoma tibiamaculata (KC249297), T. infestans (JK33877), T. braziliensis (EC917343), Rhodnius prolixus (FG544591), Aedes aegypti (XM00165064), and Drosophila melanogaster (AE0135994), and after bioinformatics sequence analysis, the primers sequences TubTmf and TubTmr were selected (Table 1).

Markers were amplified under standard polymerase chain reaction (PCR) assays as described previously; the reaction was carried out in a final volume of $25 \mu \mathrm{l}$ containing $12.5 \mu \mathrm{l}$ cocktail of PCR mix 2X (GoTaq Master Mix, Promega, Madison, WI, USA. Cat.\# M7122), $0.4 \mu \mathrm{mol}$ primers (stock $100 \mu \mathrm{M}$ ) and $5 \mathrm{ng}$ total genomic DNA; the PCR reaction was performed in an MJ Research PTC-200 thermocycler.

\section{PCR-RFLP OF THE $\boldsymbol{\beta}$-TUBULIN GENE MARKER}

The PCR fragment of the $\beta$-tubulin gene marker from specimens of different ecotopes was partially sequenced using the Sequence Navigator version 1.0.1 (Perkin Elmer Applied Biosystem) and the in silico restriction map was established (NETcutter version II). The endonucleases BamHI and KpnI (Life Technology) were selected for double digestion of the $\beta$-tubulin-PCR product following the manufacturer's instructions, and the digested DNA fragments fractionated by agarose gel electrophoresis.

\section{ELECTROPHORESIS}

The purity and integrity of the DNA were determined by electrophoresis in $0.6 \%$ agarose gel at $80 \mathrm{~V}$ for $1 \mathrm{~h}$ in TBE buffer (90 mM Tris- $\mathrm{HCl}, \mathrm{pH} 8.0 ; 90 \mathrm{mM}$ boric acid; $2.5 \mathrm{mM}$ EDTA). The PCR products were analyzed by electrophoresis on $1.5 \%$ agarose gel in TBE buffer and the RFLP products were subjected to electrophoresis in 3\% agarose gel in TBE buffer. After electrophoresis, the gel was stained with ethidium bromide, visualized with UV illumination, and recorded on a gel documentation system.

\section{GENETIC DIVERSITY}

The relationships, genetic differentiation, among the pattern fragments of the RFLP analysis of the $\beta$-tubulin marker (presence or absence of fragments) from different states and ecotopes were estimated using the NJ algorithm and the tree is based on a Kimura 2 parameter distance matrix $(32,33)$. Statistical support for branches in the NJ tree was assessed by the bootstrap method with 1,000 replicates. The analysis was conducted using the software MEGA V.4 (34).

\section{RESULTS}

\section{PHENOTYPIC VARIABILITY}

\section{Colonization and infection of T. maculata with T. cruzi}

Of the 492 specimens of T. macula, $49.2 \%$ were M; the insects were collected from six Venezuelan states, whose distribution by location showed a majority of these specimens distributed in the PD $(67.07 \%)$ and domestic (26\%) ecotopes, followed to a lesser extent by the wild ecotopes $(7.3 \%)$. On average, $20.73 \%$ of these 
Table 1 | Molecular markers, primers, and PCR assay conditions.

\begin{tabular}{|c|c|c|c|c|}
\hline Marker & Primers $5^{\prime}-3^{\prime}$ & $\begin{array}{l}\text { PCR assay } \\
\text { cycles }\end{array}$ & $\begin{array}{l}\text { Fragment } \\
\text { size }(p b)\end{array}$ & Reference \\
\hline $\mathrm{mtCyt} \mathrm{b}$ & 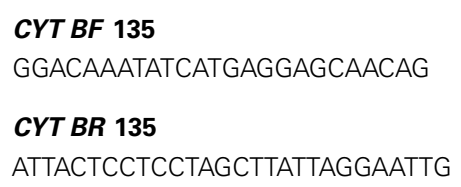 & $\begin{array}{l}94^{\circ} \mathrm{C}, 5^{\prime} \\
94^{\circ} \mathrm{C}, 30^{\prime \prime} \\
55^{\circ} \mathrm{C}, 30^{\prime \prime} \\
72^{\circ} \mathrm{C}, 30^{\prime \prime} \\
72^{\circ} \mathrm{C}, 5^{\prime}\end{array}$ & 600 & $(28,29)$ \\
\hline
\end{tabular}

$C y=$ number of cycles; ${ }^{\prime}=$ min;" $=s$.

Table 2 | Geographical origin and ecotope of Triatoma maculata.

\begin{tabular}{|c|c|c|c|c|c|c|c|c|}
\hline \multirow[t]{2}{*}{ State $^{\mathrm{a}}$ (total/F/M) } & \multirow[t]{2}{*}{ Location } & \multicolumn{2}{|c|}{ Coordinates } & \multicolumn{3}{|c|}{ Ecotopes } & \multirow[t]{2}{*}{$\mathrm{CI}(\%)$} & \multirow[t]{2}{*}{ II (\%) } \\
\hline & & $\mathbf{N}$ & $\mathbf{W}$ & D & PD & $\mathbf{S}$ & & \\
\hline \multirow[t]{6}{*}{ Anzoátegui (284/134/150) } & Pico de Neverí & $09^{\circ} 75^{\prime}$ & $065^{\circ} 02^{\prime}$ & 0 & 13 & 0 & 22.3 & 18.4 \\
\hline & El Enial & $09^{\circ} 79^{\prime}$ & $065^{\circ} 02^{\prime}$ & 0 & 33 & 4 & & \\
\hline & San José de las Margaritas del Llano & $09^{\circ} 79^{\prime}$ & $065^{\circ} 02^{\prime}$ & 33 & 94 & 5 & & \\
\hline & Los Ranchos & $10^{\circ} 23^{\prime}$ & $064^{\circ} 60^{\prime}$ & 29 & 40 & 0 & & \\
\hline & Guastrantal & $10^{\circ} 11^{\prime}$ & $064^{\circ} 59^{\prime}$ & 0 & 23 & 7 & & \\
\hline & Mundo nuevo & $09^{\circ} 30^{\prime}$ & $064^{\circ} 35^{\prime}$ & 1 & 2 & 0 & & \\
\hline \multirow[t]{4}{*}{ Monagas (86/52/34) } & Caripito & $09^{\circ} 98^{\prime}$ & $063^{\circ} 49^{\prime}$ & 9 & 4 & 8 & 13.81 & 26.8 \\
\hline & Aragua de Maturín & $09^{\circ} 77^{\prime}$ & $063^{\circ} 15^{\prime}$ & 6 & 29 & 3 & & \\
\hline & Musu & $09^{\circ} 61^{\prime}$ & $063^{\circ} 08^{\prime}$ & 8 & 5 & 5 & & \\
\hline & La Planchada & $09^{\circ} 93^{\prime}$ & $063^{\circ} 40^{\prime}$ & 0 & 7 & 0 & & \\
\hline \multirow[t]{2}{*}{ Portuguesa $(63 / 37 / 26)$} & Jabillal & $09^{\circ} 42^{\prime}$ & $069^{\circ} 18^{\prime}$ & 10 & 18 & 3 & 5.47 & 19.1 \\
\hline & Las panelas & $08^{\circ} 58^{\prime}$ & $069^{\circ} 58^{\prime}$ & 6 & 20 & 6 & & \\
\hline \multirow[t]{4}{*}{ Sucre $(29 / 15 / 14)$} & La Sabana & $10^{\circ} 18^{\prime}$ & $064^{\circ} 21^{\prime}$ & 0 & 3 & 1 & 1.76 & 37.9 \\
\hline & Guayabal & $10^{\circ} 13^{\prime}$ & $064^{\circ} 42^{\prime}$ & 2 & 4 & 3 & & \\
\hline & La Piscina & $10^{\circ} 42^{\prime}$ & $064^{\circ} 19^{\prime}$ & 2 & 6 & 1 & & \\
\hline & UDO Cumana & $10^{\circ} 46^{\prime}$ & $064^{\circ} 14^{\prime}$ & 0 & 4 & 3 & & \\
\hline \multirow[t]{5}{*}{ Bolívar (16/7/9) } & Caruachi & $08^{\circ} 35^{\prime}$ & $062^{\circ} 54^{\prime}$ & 0 & 2 & 0 & 8.2 & 18.7 \\
\hline & Guasipati & $08^{\circ} 30^{\prime}$ & $062^{\circ} 64^{\prime}$ & 3 & 3 & 0 & & \\
\hline & Tocoma & $08^{\circ} 18^{\prime}$ & $062^{\circ} 84^{\prime}$ & 0 & 4 & 0 & & \\
\hline & Gran sabana & $08^{\circ} 13^{\prime}$ & $062^{\circ} 74^{\prime}$ & 0 & 3 & 0 & & \\
\hline & La laguna & $08^{\circ} 00^{\prime}$ & $062^{\circ} 64^{\prime}$ & 0 & 1 & 0 & & \\
\hline \multirow[t]{4}{*}{ Nueva Esparta $(8 / 3 / 5)$} & Porlamar & $10^{\circ} 95^{\prime}$ & $063^{\circ} 88^{\prime}$ & 0 & 2 & 0 & 0 & 12.5 \\
\hline & Roble & $11^{\circ} 06^{\prime}$ & $063^{\circ} 84^{\prime}$ & 0 & 2 & 0 & & \\
\hline & Fuentidueño & $10^{\circ} 90^{\prime}$ & $063^{\circ} 96^{\prime}$ & 0 & 1 & 0 & & \\
\hline & La sierra & $10^{\circ} 99^{\prime}$ & $063^{\circ} 91^{\prime}$ & 0 & 3 & 0 & & \\
\hline
\end{tabular}

${ }^{a}$ Venezuela states.

$N$, total number of insects; $F$, female; $M$, male; $D$, domestic; $P D$, peridomestic; $S$, wild; $C l$, colonization Index; II, infection index.

specimens were positive for T. cruzi according to the specific kDNA and mini-exon-PCR assays (Table 2). The higher CI found in Anzoátegui and Monagas states in relation to the other states coupled to a high II to T. cruzi in these two states suggests a higher rate of household colonization and showed the importance of T. maculata as a vector. 


\section{Size and shape variation}

Average size of the membrane region of the wing was $1,984 \mathrm{~mm}$ for $\mathrm{F}$ and $1,786 \mathrm{~mm}$ for $\mathrm{M}$. The discriminate function for gender re-classified wings, $75 \%$ for $\mathrm{M}(\mathrm{M} \mathrm{30/40)}$ and $82 \%$ for $\mathrm{F}$ (F 33/40); this function in turn contained $94 \%$ of gender variance, showing significant differences in the formation of the wing according to gender (Wilk's lambda: 0.543 and 0.754 for $M$ and F respectively; $p<0.001)$. When analyzing the intraspecific allometric effect (degree of deformation of the wing), using size (component 1) as the independent variable and wing conformation (component 2) as the dependent variable, the contribution of these components was $49.5 \%$ of the variation. The differences in conformation based on the deformation of grids made by discriminating analysis disclosed that the $M$ has a lower degree of variation compared with $\mathrm{F}$, and a clear sexual dimorphism (Figure 1B). The mean wing deformation $(\overline{\mathrm{X}})$, obtained through the overlapping of gender-related wing deformation grids, showed changes in the landmark points; the decrease in wing size was observed in at least one of the landmarks (PAR 1-9) and in some cases by the loss of anatomical landmarks (Figure 1B). The same changes of the landmark points were found after the third filial generation in colonies from the same location established in the laboratory.

The formation of wing architecture based on the variation of CS in each ecotope (Figure 2) evidenced an association between $\mathrm{PD}$ and $\mathrm{S}$ insects with no significant difference between them $(p=0.0392$ for $\mathrm{PD}$ and $p=0.0382$ for $\mathrm{S})$, whereas significant differences $(p=0.0051)$ were observed when comparison was carried out between PD and S specimens together with insects collected in $\mathrm{D}$, regardless of gender (Figure 2).

The variation in wing size and conformation allowed the grouping of three states (Figure 3). The results showed clusters of $M$ and F of T. maculata captured in S and PD ecotopes in Anzoátegui, Monagas, and Portuguesa. Interestingly, higher variation in the consensus tendency was found in both genders in specimens captured in D ecotopes of Anzoátegui and Monagas (Figure 3, squares $a$ and $b$ ).

\section{GENETIC DIVERSITY}

\section{Mini-exon analysis}

Twenty percent of specimens were identified as positive for $T$. cruzi infection and $1.2 \%$ presented a co-infection with $T$. rangeli as demonstrated by a PCR assay for the mini-exon. The lineage of T. cruzi circulating in all states was identified as TcI after amplification of a band of $200 \mathrm{bp}$ from the non-transcribed region of the mini-exon (results not shown).

\section{Variability of molecular markers}

Genomic DNA from specimens of $T$. maculata representative of each state, regardless of location or ecotope, was evaluated by amplification of $\mathrm{mtC} y t \mathrm{~b}$ and the $\beta$-tubulin gene region (Table 1; Figure 4). The results showed a unique PCR product of $600 \mathrm{bp}$ for $\mathrm{mtCyt} \mathrm{b}$ (Figure 4A), which was common in size among specimens of different locations of different states and also among the ecotopes of these locations; the low variability of this product, as determined by partial sequencing, did not allow to establish differences based on mtCyt b between specimens (results non-shown).

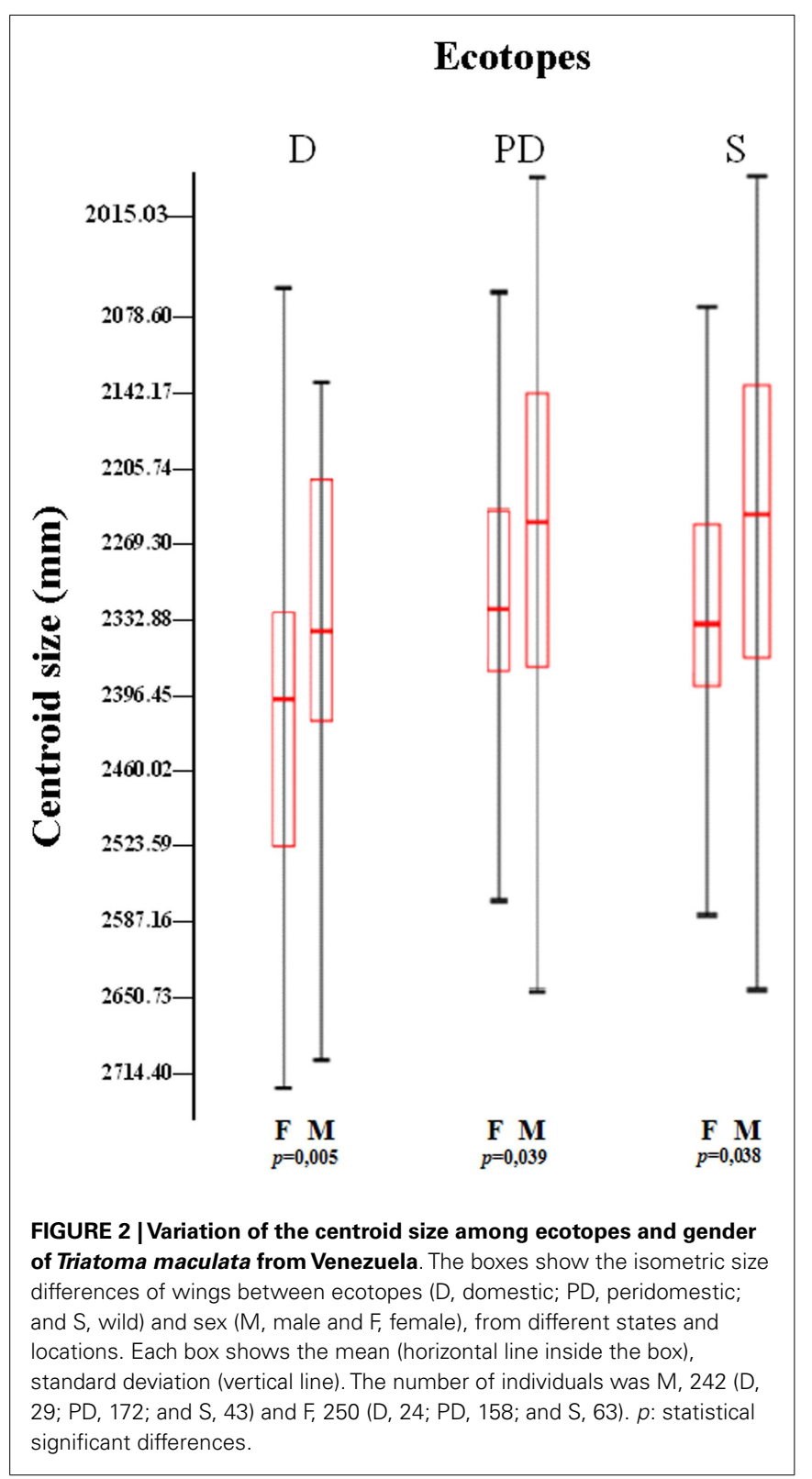

In contrast, a unique fragment of $980 \mathrm{bp}$ was generated by the amplification of the $\beta$-tubulin marker (Figure 4B); the partial sequencing of this fragment showed differences between states and ecotopes, suggesting genetic variability in populations of $T$. maculata.

In order to establish the variability of the $\beta$-tubulin gene marker, the PCR product from specimens of different states and ecotopes was sequenced and in silico restriction fragment maps were established and used to identify the restriction enzymes to be used to evaluate genetic differences among specimens from different ecotopes using RFLP analysis. The results revealed a partial common pattern for double digestion with BamHI-KpnI, with quantitative and qualitative differences among specimens of the majority of states, represented for bands of 980 (a), 620 (b), 450 (c), and $300 \mathrm{bp}$ (d) (Figure 4C). This pattern was independent of location 


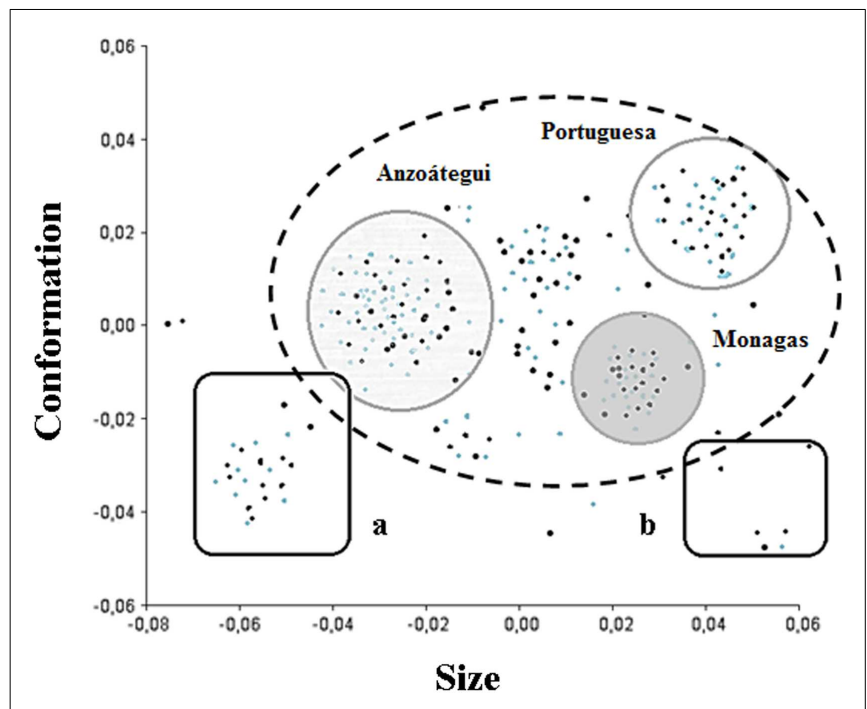

FIGURE 3 | Phenotypic variability of Triatoma maculata. Diagram of factorial data of the main components of wing architecture of T. maculata. The components size and conformation make the higher contribution (70\%) in wing variability. The dashed line circle represents the standard group, whereas the solid line ones represent groupings by confidence ellipses (95\%) of male (black points) and female (gray points) specimens from Anzoátegui, Monagas, and Portuguese states. The boxes represent the grouping of $\mathrm{M}$ and $\mathrm{F}$ specimens that showed the greatest differences in wing size and shape when compared to the consensus configuration.

or ecotope, the exception being Portuguesa state, where differences were found between ecotopes, since in this location only band (c) was present in the $S$ pattern. In addition, other individual fragments were observed among the different ecotopes in all states; however, differences between ecotopes of the same state were evident, e.g., Anzoátegui, Sucre, Monagas, and Portuguesa (Figure 4C, lanes 1-9 and 16-18), as well as between the same ecotope when different states were compared (Figure 4C, lanes 1, 4,7 , and 16).

The PCR-RFLP patterns obtained for the region of $\beta$-tubulin (Figure 4C) were evaluated according to the presence or absence of bands to establish comparative marker variability among different states and particularly among ecotopes. Anzoátegui and Monagas states had the largest differences in pattern by ecotopes (genetic differentiation index, Fst $0.476, p=0.019$ ). Anzoátegui state showed a $60 \%$ similarity between PD and S ecotopes, and the remaining $40 \%$ was due to $\mathrm{D}$ ecotope. The rest of the states revealed similar groupings in their genetic profiles (Figure 4C). This suggests that the restriction patterns obtained could be an alternative for intraspecific differentiation of T. maculata associated with different ecotopes. Comparative analysis of data from Anzoátegui and Monagas states showed that about $60 \%$ of the restriction fragments are common regardless of ecotope. Maximum Parsimony analysis with 1,000 replicates, statistically supported by bootstrapping, generating a similar clustering among specimens of $S$ and $P D$ ecotopes, which would indicate similarity, while the genetic pattern of D differs, causing it to clump as a synapomorphic group (Figure 5), separated according to ecotopes.

\section{DISCUSSION}

The present study demonstrated for the first time domiciliary adaptation processes of T. maculata in several Venezuelan states, using two approaches, phenotypic as the geometric morphometry of wing, and genotypic as the variability of the $\beta$-tubulin molecular marker. This, together with the presence of nymphs in houses and a high rate of infection with T. cruzi of specimens captured inside the home indicates that there is increased risk factor in the transmission of Chagas disease in Venezuela. Our results showed that there is discrimination of T. maculata according to its ecotopes, since specimens from S and PD ecotopes were more similar between them in wing architecture and variability of the $\beta$-tubulin marker in comparison with that from $\mathrm{D}$ ecotope. Previous studies suggest that T. maculata is contributing to increased risk of transmission of $T$. cruzi in the human population from various regions of Venezuela, particularly in the north-eastern region where specimens of this species showed a high percentage of infestation and a high rate of infection with T. cruzi (35).

Our results demonstrate the utility of geometric morphometry study of wing architecture to establish sexual dimorphism, phenotypic variability, and the association of these variables to different ecotopes of $T$. maculata. Thus, this is a robust tool to determine intraspecific differences possibly related to the geographical distribution in the macro- and microenvironment.

It has been demonstrated that Chagas disease vectors traditionally considered exclusively $S$ have the possibility to change their behavior and colonize D habitat, with a high risk in the epidemiology of the disease (36). The association with particular habitats or ecotopes of different phenotypical and genotypical characters in triatomines has proved important in vector identification, dispersion, and colonization properties and in general in the epidemiology and control of Chagas disease in South America (14, 37-39).

Different molecular strategies have been used to study genetic diversity in populations of triatomine vectors, such as variability of the mtCyt b gene, microsatellites, and random amplified polymorphic DNA (RAPD) $(14,28,37,40)$. Previous studies on the genetic variability of $T$. maculata in Venezuela using $\operatorname{mt} C y t$ b partially enabled to infer the occurrence of different haplotypes for populations in Anzoátegui and Portuguesa (4). In our study, mtCyt b presented the lowest level of variability, and these variations failed to discriminate T. maculata by ecotopes.

The polymorphism for $\beta$-tubulin marker in specimens of $T$. maculata generated evident variations between ecotopes of different locations of the Venezuelan states. This was particularly seven haplotypes for samples collected in homes and five haplotypes for copies of PD and wild ecotopes. The correspondence observed between phenotypic and genotypic grouping indicates that the joint application of both approaches is a robust tool for the study of vector domiciliation.

This is the first time that the molecular marker of $\beta$-tubulin was used for evaluation of the genetic variability in T. maculata, the evaluation of this sequence being important in establishing it for use as a valuable tool in the genetic evaluation of triatomine population. 


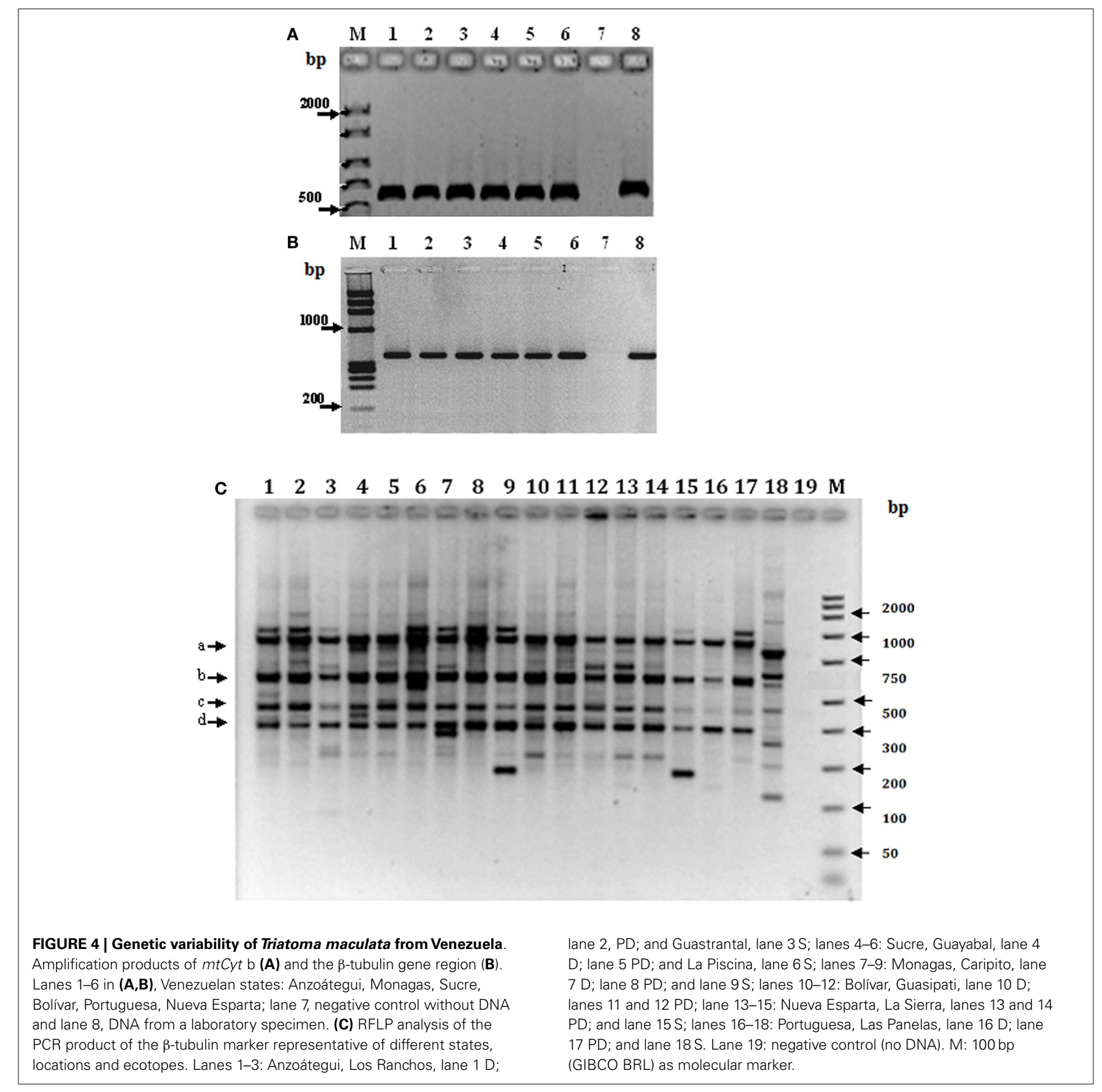

\section{CONCLUSION}

This work presents for the first time the relationship between phenotypic and genotypic approaches in the discrimination of T. maculata, a vector of Chagas disease, according to its ecotopes in Venezuela. Wing architecture and variability of the $\beta$-tubulin DNA region, the variables used to differentiate T. maculata populations, showed that specimens from S and PD ecotopes were more similar between them than those captured in the D ecotope which, together with the presence of nymphs in the houses and a high rate of infection with T. cruzi of D specimens, increases the risk factor in the transmission of Chagas disease in Venezuela.
Eradication of the vector in the domestic ecotopes followed by vigilance of re-infection will be important in reducing transmission of Chagas disease; however, integrative research is necessary to understand the vector population structure, domiciliation, and parasitic transmission.

\section{AUTHOR CONTRIBUTIONS}

Leidi Herrera (Coordinator), Roberto García-Alzate, Antonio Morocoima, and Rafael Matías Reyes-Lugo, designed the field work. Roberto García-Alzate, Daisy Lozano-Arias, Leidi Herrera, and Alexis Mendoza-León performed analyses. Roberto 


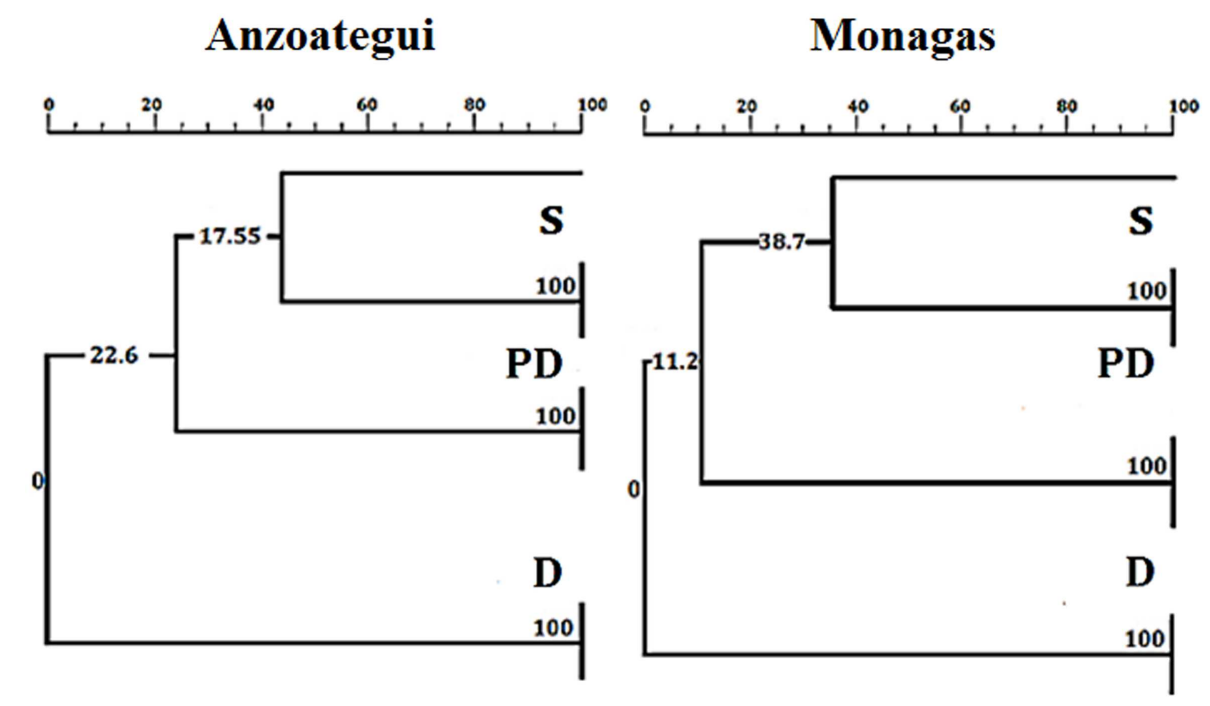

\section{Monagas}

FIGURE 5 | Neighbor-joining tree based on Kimura 2-parameters of RFLP fragments of the $\beta$-tubulin marker of Triatoma maculata. The numbers on the branches indicate boostrap support. D, PD, and S:

domestic, peridomestic, and wild ecotopes. The same tree as for Monagas was found for Sucre, Bolívar, Nueva Esparta, and Portuguesa states.

García-Alzate, Daisy Lozano-Arias, and Alexis Mendoza-León analyzed the data and prepared the manuscript. All authors read and approved the final manuscript.

\section{ACKNOWLEDGMENTS}

The project received financial support from FONACIT 2011000470 and CDCH PG038171-2011/1 (LH); CDCH PG038121-2011/1 and CDCH AIA03-8449-2012 (AM-L). Roberto García-Alzate was supported by FONACIT scholarship and Daisy Lozano-Arias FONACIT, as researcher assistant. We are most grateful to Ana Herrera, Ph.D. (IBE-UCV) for critical reading and comments of the manuscript.

\section{REFERENCES}

1. World Health Organization (WHO). Chagas Disease (American Trypanosomiasis). Fact Sheet $\mathrm{N}^{\circ} 340$ (2014). Available from: http://www.who.int/mediacentre/ factsheets/fs340/en/index.html

2. Añez N, Crisante G, Rojas A. Update on Chagas disease in Venezuela. A review. Mem Inst Oswaldo Cruz (2004) 99(8):781-7. doi:10.1590/S007402762004000800001

3. Rojas M, Várquez P, Villarreal M, Velandia C, Vergara L, Morán Y, et al. Estudio seroepidemiológico y entomológico sobre la enfermedad de Chagas en un área infestada por Triatoma maculata (Erichson 1848) en el centrooccidente de Venezuela. Cad Saude Pub (2008) 24(10):2323-33. doi:10.1590/ S0102-311X2008001000013

4. González-Brítez N, Morocoima A, Martínez C, Carrasco HJ. Infección por Trypanosoma cruzi y polimorfismo del citocromo B del ADN mitocondrial en Triatoma maculata de Anzoátegui y Portuguesa, Venezuela. Bol Mal Salud Amb (2010) L(1):85-93. Available from: http://www.scielo.org.ve/pdf/bmsa/v50n1/ art09.pdf

5. Schofield CJ, Diotaitui L, Dujardin JP. The process of domestication in Triatominae. Mem Inst Oswaldo Cruz (1999) 94(1):375-8. doi:10.1590/S007402761999000700073

6. Reyes-Lugo M. Panstrongylus geniculatus Latreille 1811 (Hemiptera: Reduviidae: Triatominae), vector de la enfermedad de Chagas en el ambiente domiciliario del centro-norte de Venezuela. Rev Biomed (2009) 20(3): 180-205. Available from: http://www.revbiomed.uady.mx/pdf/rb092034.pdf

7. Morocoima A, Sotillo E, Salaverría C, Maniscalchi M, Pacheco F, Chique D. Domiciliación del vector peridomiciliario de la enfermedad de Chagas, Triatoma maculata (Ericsson 1848) en caserío rural del norte del estado Anzoátegui. Acta Cient Venez (2004) 55(1):215.

8. Dujardin JP, Bermúdez H, Casini C, Schofield CJ, Tibayrenc M. Metric differences between wild and domestic Triatoma infestans (Hemiptera: Reduviidae) in Bolivia. J Med Entomol (1997) 34(5):544-51.

9. Gaspe MS, Schachter-Broide J, Gurevitz JM, Kitron U, Gürtler RE, Dujardin JP. Microgeographic spatial structuring of Triatoma infestans (Hemiptera: Reduviidae) populations using wing geometric morphometry in the Argentine Chaco. J Med Entomol (2012) 49(3):504-14. doi:10.1603/ME11176

10. Schachter-Broide J, Dujardin J, Kitron U, Gürtler RE. Spatial structuring of Triatoma infestans (Hemiptera, Reduviidae) populations from Northwestern Argentina using wing geometric morphometry. J Med Entomol (2004) 41:643-9. doi:10.1603/0022-2585-41.4.643

11. Monteiro A, Podlaha O. Wings, horns, and butterfly eyespots: how do complex traits evolve? PLoS Biol (2009) 7(2):e1000037. doi:10.1371/journal.pbio. 1000037

12. Schofield CJ, Galvao C. Classification, evolution, and species groups within the Triatominae. Acta Trop (2009) 110(2-3):88-100. doi:10.1016/j.actatropica.2009. 01.010

13. Grisales N, Gómez-Palacio A, Triana O, Angulo V, Jaramillo N, Parra-Henao G, et al. Diferenciación genética de tres poblaciones colombianas de Triatoma dimidiata (Latreille, 1811) mediante análisis molecular del gen mitocondrial ND4. Biomédica (2010) 30(2):207-14. Available from: http://www.redalyc.org/ pdf/843/84316246008.pdf

14. Márquez E, Jaramillo N, Gómez-Palacio A, Dujardin JP. Morphometric and molecular differentiation of a Rhodnius robustus-like form from $R$. robustus Larousse, 1927 and $R$. prolixus Stal, 1859 (Hemiptera, Reduviidae). Acta Trop (2011) 120(1-2):103-9. doi:10.1016/j.actatropica.2011.06.009

15. Monteiro FA, Barrett TV, Fitzpatrick S, Cordon-Rosales C, Feliciangeli D, Beard CB. Molecular phylogeography of the Amazonian Chagas disease vectors Rhodnius prolixus and Rhodnius robustus. Mol Ecol (2003) 12(4):997-1006. doi:10.1046/j.1365-294X.2003.01802.x

16. Dujardin JP, Shcofield CJ, Tibayrenc M. Population structure of Andean Triatoma infestans allozyme frequencies and their epidemiological relevance. Med Vet Entomol (1998) 12(1):20-9. doi:10.1046/j.1365-2915.1998.00076.x

17. Feliciangeli MD, Carrasco H, Patterson JS, Suarez B, Martínez C, Medina M. Mixed domestic infestation Rhodnius prolixus Stal, 1859 and Panstrongylus geniculatus Latreille, 1811, vector incrimination, and seroprevalence for Trypanosoma cruzi among inhabitants in El Guamito, Lara State, Venezuela. Am J Trop Med Hyg (2004) 71(4):501-5. Available from: http://www.ajtmh.org/content/71/4/ 501.long 
18. Soto-Vivas A, Liria J, De Luna E. Morfometría geométrica y filogenia en Rhodniini (Hemiptera, Reduviidae) de Venezuela. Act Zool Mex (2011) 27(1):87-102. Available from: file:///Users/eli/Downloads/27(1)07-Soto-Vivas.pdf

19. Schofield CJ. Biosystematics of the Triatominae. In: Service MW, editor. Biosystematics of Haematophagous Insects. Oxford: Clarendon Press (1988). p. 284-312.

20. Espinoza-Gómez F, Maldonado-Rodríguez A, Coll-Cárdenas R, HernándezSuárez CM, Fernández-Salas I. Presence of Triatominae (Hemiptera: Reduviidae) and risk of transmission of Chagas disease in Colima. México. Mem Inst Oswaldo Cruz (2002) 97(1):25-30. doi:10.1590/S0074-02762002000100002

21. Bautista NL, García de la Torre GS, De Haro I, Salazar-Shettino PM. Importance of Triatoma pallidipennis (Hemiptera: Reduviidae) as a vector of Trypanosoma cruzi (Kinetoplastida: Trypanosomatidae) in the state of Morelos, México and possible ecotopes. J Med Entomol (1999) 36(3):233-5.

22. Pavia PX, Vallejo GA, Montilla M, Nicholls RS, Puerta CJ. Detection of Trypanosoma cruzi and Trypanosoma rangeli infection in triatomine vectors by amplification of the histone H2A/SIRE and the sno-RNA-C11 genes. Rev Inst Med Trop S Paulo (2007) 49(1):23-30. doi:10.1590/S0036-46652007000100005

23. Bookstein FL. Morphometric Tools for Landmark Data: Geometry and Biology. New York: Cambridge University Press (1991). 435 p.

24. Rohlf FJ. TpsRelw, Program Provides a Low Dimensional Approximation (Via a Principal Components Analysis) to the Tangent Space Approximation of Shape Space, Version 1.37. State University of New York at Stony Brook (2003). Available from: http://life.bio.sunysb.edu/morph/index.html

25. Klingenberg CP. MorphoJ: an integrated software package for geometric morphometrics. Mol Ecol Resour (2011) 11(2):353-7. doi:10.1111/j.1755-0998.2010. 02924.x

26. Britto C, Cardoso MA, Wincker P, Morel CM. A simple protocol for the physical cleavage of Trypanosoma cruzi kinetoplast DNA present in blood samples and its use in polymerase chain reaction (PCR)-based diagnosis of chronic Chagas disease. Mem Inst Oswaldo Cruz (1993) 88(1):171-2. doi:10.1590/S007402761993000100030

27. Fernandes O, Santos SS, Cupolillo E, Mendoça B, Derre R, Junqueira AC, et al. A mini-exon multiplex polymerase chain reaction to distinguish the mayor groups of Trypanosoma cruzi and T. rangeli in the Brazilian Amazon. Trans $R$ Soc Trop Med Hyg (2001) 95(1):97-9. doi:10.1016/S0035-9203(01)90350-5

28. Monteiro FA, Wesson DM, Dotson EM, Schofield C, Beard CB. Phylogeny and molecular taxonomy of the Rhodniini derived from mitochondrial and nuclear DNA sequences. Am J Trop Med Hyg (2000) 62(4):460-5. Available from: http://www.ajtmh.org/content/62/4/460.long

29. Marcilla A, Bargues MD, Abad-Franch F, Panzera F, Carcavallo RU, Noireau F, et al. Nuclear rDNA ITS-2 sequences reveal polyphyly of Panstrongylus species (Hemiptera: Reduviidae: Triatominae), vectors of Trypanosoma cruzi. Infect Genet Evol (2002) 1(3):225-35. doi:10.1016/S1567-1348(02)00029-1

30. Mendoza-León A, Luis L, Fernandes O, Cupolillo E, García L. Molecular markers for species identification in the Leishmania subgenus Viannia. Trans R Soc Trop Med Hyg (2002) 96(1):65-70. doi:10.1016/S0035-9203(02)90053-2

31. Mendoza-León A, Luis L, Martinez C. The $\beta$-tubulin gene region as a molecular marker to distinguish Leishmania parasites. In: de Muro A, Rapley R, editors. Methods in Molecular Biology: Gene Probes Principles and Protocols (Vol. 179), Totowa, NI: Human Press (2002). p. 61-83.
32. Saitou N, Nei M. The neighbor-joining method: a new method for reconstructing phylogenetic trees. Mol Biol Evol (1987) 4(4):406-25.

33. Kimura MA. Simple method for estimating evolutionary rates of base substitutions through comparative studies of nucleotide sequence. J Mol Evol (1980) 16(2):111-20. doi:10.1007/BF01731581

34. Tamura K, Dudley J, Nei M, Kumar S. MEGA4: molecular evolutionary genetics analysis (MEGA) software version 4.0. Mol Biol Evol (2007) 24(8):1596-9. doi:10.1093/molbev/msm092

35. Morocoima A, Chique J, Zavala-Jaspe R, Díaz-Bello Z, Ferrer E, UrdanetaMorales S, et al. Commercial coconut palm as an ecotope of Chagas disease vectors in north-eastern Venezuela. J Vector Borne Dis (2010) 47(2):76-84. Available from: http://www.mrcindia.org/journal/issues/472076.pdf

36. Patterson JS, Guhl F. Geographical Distribution of Chagas Disease. 1st ed. In: Telleria J, Tibayrenc M, editors. American Trypanosomiasis Chagas Disease. One Hundred Years of Research. Elsevier (2010). p. 91-122.

37. Carvallo-Costa FA, Dos Santos SM, Pires MQ, Lopes CM, Noireau F, Pacheco R. Sylvatic and peridomestic population of Triatoma pseudomaculata are not significant structures by habitat, as revealed by two genetic markers. $J$ Vector Ecol (2010) 35(2):295-300. doi:10.1111/j.1948-7134.2010.00085.x

38. Hernández L, Abrahan L, Moreno M, Gorla D, Catal S. Phenotypic variability associated to genomic changes in the main vector of Chagas disease in the southern cone of South America. Acta Tropic (2008) 106(1):60-7. doi:10.1016/j.actatropica.2008.01.006

39. Dujardin JP, Beard CB, Ryckman R. The relevance of wing geometry in entomological surveillance of Triatominae, vectors of Chagas disease. Infect Genet Evol (2007) 7(2):161-7. doi:10.1016/j.meegid.2006.07.005

40. Goubiere S, Dorn P, Tripet F, Dumontiel E. Genetic and evolution of triatominos: from phylogeny to vector control. Heredity (2012) 108(3):190-202. doi:10.1038/hdy.2011.71

Conflict of Interest Statement: The authors declare that the research was conducted in the absence of any commercial or financial relationships that could be construed as a potential conflict of interest.

Received: 02 August 2014; accepted: 17 September 2014; published online: 30 September 2014.

Citation: García-Alzate R, Lozano-Arias D, Reyes-Lugo RM, Morocoima A, Herrera L and Mendoza-León A (2014) Triatoma maculata, the vector of Trypanosoma cruzi, in Venezuela. Phenotypic and genotypic variability as potential indicator of vector displacement into the domestic habitat. Front. Public Health 2:170. doi: 10.3389/fpubh.2014.00170

This article was submitted to Epidemiology, a section of the journal Frontiers in Public Health.

Copyright (C) 2014 García-Alzate, Lozano-Arias, Reyes-Lugo, Morocoima, Herrera and Mendoza-León. This is an open-access article distributed under the terms of the Creative Commons Attribution License (CC BY). The use, distribution or reproduction in other forums is permitted, provided the original author(s) or licensor are credited and that the original publication in this journal is cited, in accordance with accepted academic practice. No use, distribution or reproduction is permitted which does not comply with these terms. 